\title{
Ethnomedicinal, Antimicrobial and Antidiarrhoeal Studies on the Mangrove Plants of the Genus Xylocarpus: A Mini Review
}

\author{
Swagat Kumar Das, Dibyajyoti Samantaray and Hrudayanath Thatoi*
}

Department of Biotechnology, College of Engineering and Technology, Biju Patnaik, University of Technology, Bhubaneswar-751003, Odisha, India

\begin{abstract}
Mangroves being stress tolerant plants possess unique metabolites with significant amount of bioactive compounds which could be isolated and evaluated for possible drug development with suitable biotechnology tools. The mangrove genus Xylocarpus comprises of four species viz. Xylocarpus granatum (Koenig), X. moluccensis (lamk.) and $X$. mekongensis Pierre and $X$. rumphii. However, $X$. rumphii is a less abundant mangrove plant. There have been reports that different species of Xylocarpus are used ethnomedicinally for treatment of various diseases such as fever, malaria, cholera, diarrhoea, swelling of breast, elephantiasis, inflammation, dyslipidemia, pain, hyperglycaemia etc. Recent studies revealed that the extracts from different parts of the plant such as leaves, stem, bark and fruits possess phytoconstituents like alkaloids, glycosides, steroids, limnoids, terpenoids, flavonoids, tannins and other phenolics. Further, it has been established that the different solvent extracts of the plants have exhibited antimicrobial and antidiarrhoeal activities against a number of human pathogens which could be correlated to their phytoconstituents such as flavonoids, alkaloids, limnoids, tannins etc. The present study is aimed at compiling information on phytochemical, pharmacological and ethnomedicinal properties of mangrove plants of genus Xylocarpus, with a view to critically assess the legitimacy of the use of these plants for antimicrobial and antidiarrhoeal activities as well as providing directions for further research.
\end{abstract}

Keywords: Mangrove; Xylocarpus; Ethnomedicine; Phytochemical; Antimicrobial; Antidiarrhoeal

\section{Introduction}

Plants and plant based metabolites are widely used in ethnomedicinal practices around the world. Plants are rich in wide variety of secondary metabolites such as tannins, terpenoids, alkaloids, flavonoids, flanonoids, phonolics, glycosides, saponins, and steroids etc. which have been used for treatment of various diseases for ages. Like any other plant communities, the mangrove plants have also been reported for there ethnomedicinal uses. Mangroves are the unique plant communities inhabiting the estuarine and intertidal regions of both tropical and subtropical coasts are largely confined to the region between $30^{\circ}$ north and south of the equator. These are salt tolerant plant communities comprising of trees, herbs, shrubs and grasses. There are about 39.3 million acres of mangrove forests in the warm coastlines of tropical oceans all over the world distributed in 112 countries and territories [1]. Out of the given total mangrove species and their associates, the number of exclusive or true mangrove species in the world is 68 and they belong to 27 genera. Approximately 55 species of mangroves from 22 genera were distributed in Indian Ocean region [2]. These plants inhabit an extremely challenging environmental abiotic stress condition enumerated by high salinity, water logging condition, high and low tides of water, high temperature, low oxygen, low nutrition, muddy anaerobic soil and strong wind conditions where other plants cannot grow. Along with these abiotic stress factors, the insects and microorganisms and other anthropological condition also contribute a large in developing the biotic stress to these unique plant community. However, these mangrove plants adapted well to these ecological hostile condition by alterations in their physiological processes resulting in the synthesis of novel chemical compounds that offer protection to these plants against various biotic and abiotic stresses mentioned above [3]. A number of these phytocompounds or secondary metabolites have significant pharmacological properties are being used traditionally for treatment of number ailment [4].

For centuries, mangroves have been traditionally used for food (fruits and nectar), feed and medicinal purposes in different parts of the world. They are well known to produce natural metabolites with diverse biological activities. Several mangrove plants viz. Acanthus ilicifolius, Aegiceras majus, Avicennia africana, A. marina, A. officinalis, Ceriops caudolleana, Exocoecaria agallocha, Kandelia rhecdi, Nypa fruticans, Rhizophora mangle, R. mucornata and Sonneatia caseolaris are widely used by local medical practitioners in many countries like Africa, South East Asia, South America and Australia including India. These plants are used to cure some diseases like leprosy, elephantiasis, tuberculosis, malaria, dysentery, ulcers and some skin diseases [5]. The mangroves plants are reported to contain some unique class of diverse compounds that includes phorbol esters, phenolics and related compounds, steroids, triterpenes, and their glycosides, tannins, other terpenes and related compounds, flavonoids, tannins, anthocyanins, alkaloids etc [3]. A number of these compounds or secondary metabolites have significant medicinal properties that can be exploited in shaping better human health care needs.

The genus Xylocarpus consists of ethnomedicinally important mangrove plant species viz. Xylocarpus granatum, $X$. moluccensis, $X$. mekongensis, $X$. rumphii that are used in traditional medicine practices. Extracts of leaves, barks and fruits of these plants have been reported for various ethnomedicinal uses such as fever, malaria, inflammation, dysentery, diarrhoea, cholera, abdominal problems, diabetes,

*Corresponding author: Hrudayanath Thatoi, Department of Biotechnology, College of Engineering and Technology, Biju Patnaik, University of Technology, Bhubaneswar-751003, Odisha, India, Tel: +91 6742386 075; Fax: +91674 2386182; E-mail: hn_thatoi@rediffmail.com

Received October 26, 2014; Accepted November 28, 2014; Published December 01,2014

Citation: Das SK, Samantaray D, Thatoi H (2014) Ethnomedicinal, Antimicrobial and Antidiarrhoeal Studies on the Mangrove Plants of the Genus Xylocarpus: A Mini Review. J Bioanal Biomed S12: 004. doi:10.4172/1948-593X.S12-004

Copyright: ( 2014 Das SK, et al. This is an open-access article distributed unde the terms of the Creative Commons Attribution License, which permits unrestricted use, distribution, and reproduction in any medium, provided the original author and source are credited. 
elephantiasis, antimicrobials etc. Recently, these plants are also reported for their antioxidant, anticancer, antidiabetic, antidyslipidemia, antimicrobials, antidiarrhoeal, antifilarial, antiulcer and cardiotonic properties [6-14]. The comprehensive uses of Xylocarpus species in human sufferings provide strong evidence of their healing power and demands further research.

The present review aims to compile the ethnomedicinal, antimicrobial and antidiarrhoeal reports of different mangrove plants belonging to the genus Xylocarpus.

\section{Taxonomical Classification}

Kingdom: Plantae

Division: Tracheophyta

Class: Magnoliopsida

Order: Sapindales

Family: Meliaceae

Genus: Xylocarpus

Species: Xylocarpus granatum, X. moluccensis, X. mekongensis

\section{Botanical Features}

The genus Xylocarpus consists of trees growing around littoral of the tropical Indian Ocean and extending to the Pacific Islands distributed widely in the coastal areas of South-East Asia, Australia and East Africa [15]. The genus Xylocarpus belonging to the family Meliaceae has three distinct species in India viz. Xylocarpus granatum (Koenig), X. moluccensis (lamk.) and X. mekongensis Pierre [16]. However, it has been reported that another species i.e. X. rumphii belonging to the genus Xylocarpus genus inhabits sandy and rocky seashores in the tropics like Srilanka, Malaysia and some parts of Australia [17]. Out of these four species, X. rumphii appears to be less common in distribution and abundance. X. granatum commonly known as a 'cannon ball tree' is a large spreading medium mangrove tree growing in inter-tidal silty clay soil, with rounded coriaceous leaves, smooth thin bark, and abundant red heartwood forming well developed buttresses surrounding the trunk base. Mature fruits hang on the mother plants almost throughout the year. Diameter of the fruit is up to $20 \mathrm{~cm}$ or slightly more, yellowish brown fruit coat, completely round with long woody stalk. X. moluccensis is a medium-sized crooked, much branched ever green tree up to $10 \mathrm{~m}$ tall growing generally on the sandy or rocky bay, away from the frequent tidal inundation. They are found on the fringes of backwater creeks. They have pointed leaves, deeply serrated bark and an undistinguished timber. The fruit is the size of a mandarin orange of $5-7 \mathrm{~cm}$ in diameter. The $X$. mekongensis is a medium sized tree that grows generally on the inter-tidal silty but consolidated clay or on the sandy or rocky bay. The plant has well developed aerial blunt end pneumatophores or root suckers. It has green coloured fruit of diameter generally not exceeding $15 \mathrm{~cm}$. The morphological features and distribution of these plants have been summarised in (Table 1).

\section{Ethnomedicinal Reports}

Ethnomedicine refers to the study of traditional medicinal uses practised by different ethnic groups in concerned with the cultural interpretation of health, diseases and illness. The practice of ethnomedicine involves written documents, experience and knowledge that have been shared from generation to generation [18]. The ethnomedicinal study plays a vital role in drug discovery and anthropological research. It constitutes the scientific backbone for developing active therapeutics based on traditional medicines of different human indigenous societies.

Ethnomedicinal studies on X. granatum have been documented by several researchers. It has been reported that extracts of different parts of $X$. granatum are used traditionally as relief for fever including malaria, inflammation, dysentery, cholera and other abdominal problems in certain parts of the globe [19,20]. Different extracts of roots, barks [3], fruit seed coat, seed kernels [21] are used to treat cholera and treatment of diarrhoea.

$X$. mekongensis, another species of the genus Xylocarpus has been reported to have ethnomedicinal uses. The bark and pneumatophore of $X$. mekongensis possess antimalarial, antidiarrhoeal and antinociceptive activities $[3,22,23]$. Traditionally $X$. mekongensis is used as an astringent and in the treatment of fever, dysentery, diarrhoea [24]. The kernel root of this plant also reported for their anti-inflammatory properties [25].

Yet another species of the genus Xylocarpus i.e. X. moluccensis is also used in traditional medicinal practices as reported by several studies. The fruit and bark of X. moluccensis is used in the treatment of fever, malaria, antidiarrhoea, antiemetic, elephantiasis and swelling of the breast etc. [3]. An ointment prepared from seed ash of the plant $X$. moluccensis along with sulphur and coconut oil is used for treatment of itch [24]. The ethnomedicinal uses of the different species of the Xylocarpus plants have been summarized in (Table 1).

\section{Phytochemical Constituents}

The mangrove plants that belong to the genus Xylocarpus have shown enormous ethno medicinal potential; however, few reports are available about their active principles responsible for their biological activities. The presence of alkaloids, flavonoids, monoterpnes, triterpenoids, tetratriterpenoids, limonoids, phenolic acids, steroids etc. has been reported in the leaves, stem bark and fruits of these plants $[3,19]$. Numerous alkaloids have been reported in the barks, roots and fruits extracts of X. granatum [26]. Four alkaloids viz. N-methyl flindersine, chelerythrine, dihydrochelerythrine, acetonyl dihydrochelerythrine were isolated from the root barks of X. granatum [27]. Besides, its fruits also contain many alkaloids like xylogranatinin, granatoin [28-30]. Flavonoids like catechin, epicathechin, kaempferol, $3-\mathrm{O}-\beta$-D-glucoside are found in different parts (bark, fruits and leaves) of the plant $X$. granatum [19,28,31]. Similarly, the bark of $X$. moluccensis is reported to contain flavonoids like catechin and epicatechin [19]. X. granatum seeds are rich source of limonoid xylocarpin [32] and hispidol B [26]. Its bark is rich in gedunin, xyloccensins $\mathrm{L}-\mathrm{V}, 6$-dehydroxyxylocarpin D [19,33-37]. Several limnoids viz. Xyloccensin (A-I), Xylocarpin, Humilin $\mathrm{B}$ are also reported in bark and leaves extracts of $X$. moluccenesis [32]. The presence of four novel tetranotriterpenoids named xylogranatins A-D (1-4) with have been demonstrated by phytochemical exploration of seed extracts of $X$. garanatum [38]. The seeds of $X$. granatum plant have been reported to contain rich sources of tirucallane-type triterpednoids [39]. These plants are also reported to have many compounds of limonoids from its different species that include Gedunin group, Andirobin group, Mexicanolide group and Obacunol group [40]. The mangroves $X$. granatum and X. moluccenesis are distinguished for producing antifeedant limonoids especially mexicanolides and phargmalins. Recently Protoxylogranatin, a new derivative of phargmalins has been isolated from X. granatum which plays a pivotal role in oxidative cleavage in biogenetic pathway to limonoid [41]. X. granatum leaves are rich in cholesterol, campestrol, 
Citation: Das SK, Samantaray D, Thatoi H (2014) Ethnomedicinal, Antimicrobial and Antidiarrhoeal Studies on the Mangrove Plants of the Genus Xylocarpus: A Mini Review. J Bioanal Biomed S12: 004. doi:10.4172/1948-593X.S12-004

Page 3 of 7

\begin{tabular}{|c|c|c|c|}
\hline Mangrove species & Features & Occurrence & Ethnomedicinal uses \\
\hline X. garanatum & $\begin{array}{l}\text { Plant: Small to medium-sized, glabrous, evergreen tree } \\
\text { Leaf: Paripinnate, the leaves } \\
\text { have } 1 \text { or } 2 \text { pairs of leaflets. The leaflets are characteristically obovate with } \\
\text { a rounded apex. The lamina is gradually tapering towards the thick, distinct } \\
\text { petiolule. The lamina is coriaceous with a shining surface. } \\
\text { Bark: Trunk surface is pale, smooth with its thin bark peeling in flakes or patches } \\
\text { Fruit: large, globose up to } 20-30 \mathrm{~cm} \text { across. } \\
\text { Flowers: Flowers small in axillary few-flowered cymose panicles, } 4-7 \mathrm{~cm} \text { long. } \\
\text { Root: Erect, conical knee roots are absent but the horizontal cable roots develop } \\
\text { into ribbon-like plank roots }\end{array}$ & $\begin{array}{l}\text { East Africa, South east } \\
\text { asia, Australia } \\
\text { and Indian Costal } \\
\text { region }\end{array}$ & $\begin{array}{l}\text { Bark: cholera, fever, malaria, ,diarrhoea } \\
\text { Leaves: microbial, diarrhoea } \\
\text { Fruits: hyperglycaemia, } \\
\text { dyslipidemia,idiarrhoea }\end{array}$ \\
\hline X. moluccensis & $\begin{array}{l}\text { Plant: Moderate-sized trees }(5-20 \mathrm{~m} \text { in height) with well-developed woody } \\
\text { trunk } \\
\text { Leaf: Leaflets ovate } \\
\text { Bark: Bark longitudinally fissured, } \\
\text { Fruit: Fruit elliptical ( } 8-12 \mathrm{~cm} \text { in diameter) containing } 5-10 \text { seeds. } \\
\text { Flowers: Flowers tiny white to pinkish in clusters on an inflorescence. } \\
\text { Root: small or no buttress roots, many peg-shaped, pneumatophores. }\end{array}$ & $\begin{array}{l}\text { Coastal region of } \\
\text { India, Bangladesh, } \\
\text { Burma, Ceylon Malaya } \\
\text { and Indonesia }\end{array}$ & $\begin{array}{l}\text { Bark: fever, malaria, astringent, } \\
\text { febrifuge, dysentery, diarrhoea. } \\
\text { Leaves: bacterial, cancer and } \\
\text { inflammation } \\
\text { Fruits: aphrodisiac, cure } \\
\text { for elephantiasis and swelling of the } \\
\text { breasts, bactericidal. hyperglycaemia } \\
\text { and dyslipidemia }\end{array}$ \\
\hline X. mekogenesis & $\begin{array}{l}\text { Plant: Tree } 5-20 \mathrm{~m} \text { tall } \\
\text { Leaf: Paripinnate, the leaves have } 1,2 \text { or } 3 \text { pairs of leaflets. The leaflets are } \\
\text { ovate or oblong with a pointed or blunt tip. The surface of the lamina is flat. } \\
\text { Bark: Trunk surface is rough, dark brown, fissured with the bark peeling in long } \\
\text { thick narrow strips. } \\
\text { Fruit: subglobose up to } 10 \mathrm{~cm} \text { across, with } 10-15 \text { pyramidal seeds. } \\
\text { Flowers: The inflorescence } 10 \mathrm{~cm} \text { long. The flowers are creamy white with an } \\
\text { attractive orange red disc } \\
\text { Root: Horizontal cable roots produce vertical, conical, laterally compressed } \\
\text { knee roots or pneumatophores which may grow up to } 30 \mathrm{~cm} \text { tall }\end{array}$ & $\begin{array}{l}\text { Bengal, Burma, the } \\
\text { Andaman's, the } \\
\text { Malay Peninsula and } \\
\text { Archipelago, Australia, } \\
\text { Fiji } \\
\text { and Africa }\end{array}$ & $\begin{array}{l}\text { Bark: malaria, diarrhoea, } \\
\text { antinociceptive activities, inflammation } \\
\text { and oxidant } \\
\text { Fruits: elephantiasis, preventing swelling } \\
\text { of the breast }\end{array}$ \\
\hline
\end{tabular}

Table 1: Botanical features, distribution and ethnomedicinal uses of Xylocarpus plants.

\begin{tabular}{|c|c|c|c|c|}
\hline Xylocarpus species & Major Phytoconstituents & Bioactivity & Compounds Isolated & References \\
\hline$X$. granatum & $\begin{array}{l}\text { Alkaloids, } \\
\text { Steroids } \\
\text { Tannins } \\
\text { Triterpenes } \\
\text { Limonoids } \\
\text { Flavonoids } \\
\text { Saponins }\end{array}$ & $\begin{array}{l}\text { Antimicrobial } \\
\text { Antifilarial, } \\
\text { CNS-depressant activity } \\
\text { Antidiabetic } \\
\text { Antidyslipidemic } \\
\text { Antimalarial } \\
\text { Anticancer } \\
\text { Antioxidant } \\
\text { Terpenoids } \\
\text { Cardiotonic activity } \\
\text { Antifeedant }\end{array}$ & $\begin{array}{l}\text { 4-hydroxybenzoic acid, ethyl 3,4- dihydroxybenzoate, } \\
\text { xylogranatinin, granatoin, N-Methylflindersine, } \\
\beta \text {-Sitosterol, } \beta \text {-Sitosterol } \beta \text {-D-glucoside } \\
\text { Methyl angolensate } \\
\text { Gedunin and 1a-hydroxy-1,2-dihydrogedu., xyloccensin O, } \\
\text { xyloccensin } \mathrm{P}, \text { xyloccensin } \mathrm{Q} \\
\text { Catechin, epicatechin, procyanidins of the B, trimer and } \\
\text { pentamer } \\
\text { xyloccensins O-P, xyloccensins Q-V, } \\
\text { Xyloccensin L, xyloccensin K, xyloccensin IJ. } \\
\text { Chelerythrine and dihydrochelerythrine }\end{array}$ & $\begin{array}{l}{[6-7],[14],[26-27],[33],} \\
{[36-37],[40],[44-52]}\end{array}$ \\
\hline X. moluccensis & $\begin{array}{l}\text { Alkaloids, } \\
\text { Steroids, } \\
\text { Tannins, } \\
\text { Triterpenes, } \\
\text { Proanthocyanidins } \\
\text { Flavonoids } \\
\text { Limnoids }\end{array}$ & $\begin{array}{l}\text { Antiepileptic } \\
\text { Antioxidant } \\
\text { Antiradical } \\
\text { Antimicrobial } \\
\text { Cytotoxic } \\
\text { Antiulcer } \\
\text { Antifeedant }\end{array}$ & $\begin{array}{l}\text { Procyanidin decamer, procyanidin undecamer } \\
\text { Catechin, epicatechin, procyanidin B1, B3, procyanidin trimer, } \\
\text { procyanidin pentamer, procyanidin hexamer, procyanidin } \\
\text { decamer procyanidin undecamer } \\
\text { Xyloccensins X and Y } \\
\text { xylomollin }\end{array}$ & [1], [13], [19], [53-55] \\
\hline X. mekogenesis & $\begin{array}{l}\text { Tannins } \\
\text { Saponins } \\
\text { Flavonoids } \\
\text { Alkaloids } \\
\text { Steroids }\end{array}$ & $\begin{array}{l}\text { Antibacterial } \\
\text { Cytotoxic } \\
\text { Activity } \\
\text { Antidiabetic } \\
\text { Antidyslipidemic }\end{array}$ & Xylocarpin, xyloccensin & [8-9], [56-58] \\
\hline
\end{tabular}

Table 2: Phytochemical constituents and bioactivity of Xylocarpus species.

stigmasterol, sitosterol, 28-isofucosterol. Seeds and fruits of this plant contain some important sterols like ergosterol peroxide, $\beta$-sitosterol fatty acid esters [42]. The Bark of X. granatum is reported to contain procyanidin B1, procyanidin trimer and pentamer [26]. Similarly, bark of $X$. moluccensis are rich sources of variety of proanthocyanidins like procyanidin $\mathrm{B}$, procyanidin $\mathrm{B}$, procyanidin trimer, procyandin pentamer, procyanidin hexamer, procanidin decamer and procyandinin undecamer [19]. However, very few compounds are reported in $X$. mekongensis. Compounds like xyloccensin, xylocarpin are reported in different extracts of $X$. mekongensis $[3,43]$. The different species of the genus Xylocarpus along with their major phytoconstituents and bioactivity are summarized in (Table 2 ).

\section{Antimicrobial and Antidiarrhoeal Activities of Xylocarpus Sp.}

\section{Antimicrobial activity}

The phytochemicals as remedy for various ailments including microbial infections have been known for centuries which form the basis for their use in ethnomedicinal practices around the world [59]. Recently, the indiscriminate use of antibiotiotics has led to the emergence of multidrug resistant microbial strains; hence the search for novel antimicrobial compounds is the need of the hour.

Phytochemicals possessing antimicrobial activities can provide an alternative source as the natural products contains diversified chemical compounds that can be exploited scientifically for development of novel 
drugs. In this respect, mangrove plants can play a very important role as they offer a very rich source of valuable bioactive compounds and thus merit serious consideration for the discovery of novel drugs having antimicrobial properties. The antimicrobial properties of the mangrove plants have been recently attracted the researchers' worldwide since the mangrove plants possess strong antimicrobial compounds (viz. flavonoids, tannins, terpenoids, coumarins, alkaloids, lectins) that may act against a broad range of disease causing microorganisms. Patra and Mohanta [60] have reported the antimicrobial activities in several mangrove plants that include Avicennia marina, A. officinalis, Bruguiera gymnorrhiza, B.conjugate, B. sexangula, C. odorata, Ceriops decandra, Exoecaria agallocha, Heritiera littoralis, Rhizophora apiculata, R. mucronata, X. granatum.

The mangrove plants of genus Xylocarpus exhibited promising antimicrobial activities and are also reported for possession of several unique antimicrobial compounds. Several studies have shown that the bark, leaves and fruit extracts of the plant X. granatum exhibited effective antimicrobial activities against several Gram positive and Gram negative bacteria. The ethanol, petroleum ether, chloroform, carbon tetrachloride [10] and methanol [61,62] extracts of stem of $X$. granatum exhibited antimicrobial activity against various microbes like Staphylococcus aureus, S. epidermis, Shigella boydii, Proteus sp., Escherichia coli, Streptococcus pyogenes, Bacillus subtilis. Similarly, Rao and Chaitanya [47] reported the antibacterial and antiyeast activities of ethanolic extracts of leaf and stem $(100 \mathrm{mg} / \mathrm{ml}$ and $300 \mathrm{mg} / \mathrm{ml})$ of $X$. granatum. It has been suggested that different parts of the mangrove plant $X$. granatum exhibit antimicrobial properties which may be due to the presence of phytoconstituents such as alkaloids, flavonoids, tannins etc. [63]

Another species of the genus Xylocarpus, i.e. X. moluccensis also possessed promising antimicrobial properties as reported by various studies. The different parts like barks [7], pneumatophores [54], fruit husk [64], leaves [56] of X. moluccensis exhibited considerable antibacterial activity against a wide range of both Gram positive and Gram negative bacterial strains that include E. coli, Enterobacter aerogenes, Pseudomonas aeruginosa, Salmonella typhi, S. boydii, S. dysenteriae, S. flexneri, S. sonnei, Staphylococcus aureus, Staphylococcus epidermidis, S. pyogenes and Vibrio cholera, Klebsiella pneumoniae, Enterobacter aerogenes and Pseudomonas aeruginosa.

Amongst the three species of Xylocarpus, X. mekongensis have been least reported for its antimicrobial activities. However, Ahmed et al. [65] reported the antibacterial activity of different solvent extracts of bark of $X$. mekongensis against various bacterial strains viz. Vibrio cholera, S. flexneri, S. boydii, Salmonella typhi, S. paratyphi and S. aureus. The ethyl acetate and chloroform extracts of bark showed relatively higher antibacterial activity amongst the different solvent extracts studied. The details of the antimicrobial compounds from the different Xylocarpus species are described in (Table 3 ).

The antibacterial property $[66,67]$ of the different species of the mangrove genus Xylocarpus can be attributed to the presence of different secondary metabolites like flavonoids, saponins, polyphenols. Some important antimicrobial phytochemicals isolated from the mangrove plants of genus Xylocarpus have been included in (Figure 1).

\section{Antidiarrhoeal activity}

According to WHO census for developing nations, diarrhoea remains a major cause of infant mortality and morbidity [68] Though various drugs are available for treatment of diarrhoea still numerous side-effects (e.g. abdominal discomfort, dry mouth, nausea, constipation and headache) are associated with these drugs. In comparison to conventional drugs, numerous herbal antidiarrhoeal remedies from various medicinal plants are available having lesser side effects and better efficacy. The bioactive compounds from these plants exert their antidiarrhoeal activity by decreasing the gastrointestinal motility as well as the secretions in vivo [69]. Phytoconstituents like tannins, tannic acid, flavonoids, alkaloids, sesquiterpenes,

\begin{tabular}{|l|l|l|l|}
\hline Plant name & Plant part (s) used & Test method & Compounds identified \\
\hline X. granatum & $\begin{array}{l}\text { Ethanol extract of stem bark, methanolic } \\
\text { extracts of rootlet and shoot }\end{array}$ & $\begin{array}{l}\text { - Agar disc diffusion method } \\
\text { X. moluccensis }\end{array}$ & $\begin{array}{l}\text { Xexloccensin, procyanidin B3, catechin, } \\
\text { epicatechin, procyanidin B1, procyanidin trimer, procyanidin } \\
\text { pentamer, xyloccensin Q, gedunin, alkaloids,xylocarpin, } \\
\text { N-methylflindersine xylogranatins A-D }\end{array}$ \\
\hline $\begin{array}{l}\text { Acetate, Methanol, Acetone, Ethanol and } \\
\text { Water extracts of leaves and stem; } \\
\text { methanol extract of fruit husk; ethanol } \\
\text { extracts of the pneumatophores }\end{array}$ & $\begin{array}{l}\text { [10], Agar disc diffusion method } \\
\text { - Agar cup-plate diffusion } \\
\text { method }\end{array}$ & $\begin{array}{l}\text { flavonoids, alkaloids and glycosides } \\
\text { [56], [63-64] }\end{array}$ \\
\hline X. mekongensis & $\begin{array}{l}\text { methanol, ethyl acetate and chloroform } \\
\text { extracts of bark }\end{array}$ & $\begin{array}{l}\text { - Agar disc diffusion method } \\
\text { - Broth macro- dilution assay }\end{array}$ & Saponins, tannins, flavonoids \\
\hline
\end{tabular}

Table 3: Antimicrobial activities of Xylocarpus species.

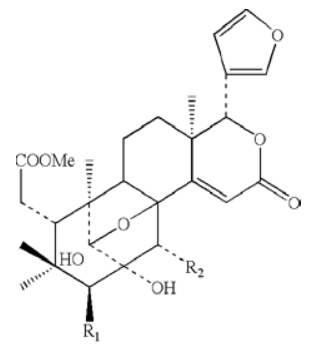

Xyloccensin<smiles>Oc1cc(O)c2c(c1)OC(c1ccc(O)c(O)c1)C(O)C2</smiles>

Catechin

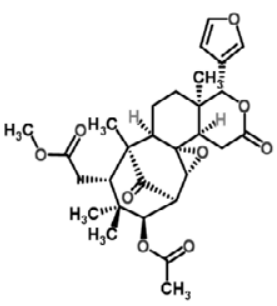

Xylocarpin

Figure 1: Structure of some antimicrobial phytoconstituents reported from Xylocarpus $s p$. 
diterpenes, terpenes and terpenoids are present in many plants that may contribute to antidiarrhoeal activity. As part of the continuing research on antidiarrhoeal activity, mangroves plants have not been left out. Different mangrove species like Carapa moluccensis, C. obovata, Heritiera littoralis, R. apiculata, R. mangle, X. garantum, X. moluccensis and $X$. mekogenesis have been reported to exhibit antidiarrhoeal activity [3].

It has been reported that the extracts of different parts of two Xylocapus species such as $X$. granatum and $X$. moluccensis are traditionally used for treatment of diarrhea. The ethanolic bark and leaves extracts of $X$. granatum showed antidiarrhoeal activity in number diarrhoeal animal models. They were found to exhibit significant antidiarrhoeal activity in a dose dependent manner [62]. The purging indices and percent purging indices for bark extracts of $X$. granatum were reported to be $32.09,22.75 \%(500 \mathrm{mg} / \mathrm{kg})$ and 14.07 , $10.30 \%(1000 \mathrm{mg} / \mathrm{kg})$ and for leaves extract as $51.56,40.66 \%(500 \mathrm{mg} /$ $\mathrm{kg})$ and $17.62,28.83 \%(1000 \mathrm{mg} / \mathrm{kg})$ respectively. The decreased percent purging indices represent the potential antidiarrheal activity of bark and leaf extracts. In another experiment, the methanol extracts of $X$. granatum bark has been reported for their antidiarrhoeal activities in experimental castor oil and magnesium sulphate induced by diarrhoeal mice. The methanol extract showed dose-dependent antidiarrhoeal activity in both models at 250 and $500 \mathrm{mg} / \mathrm{kg}$ dose as evident by reduced number of faeces and total number of diarrhoeic faeces. The antidiarrhoeic activity of these extracts may be due to antisecretory mechanism, decreased water reabsorption or delayed gastrointestinal transit [11]. Lakshmi et al. [70] also reported that fruit seed coat of $X$. garantum showed promising antidiarrheal activity at $500 \mathrm{mg} / \mathrm{kg}$ dose level in castor oil induced diarrhoeal mice model. The ethanol extracts of the fruit on further fractionation leads to isolation of many bioactive molecules [71] like gedunin, photogedunin, palmitic acid as listed in (Table 4).

Another species of the mangrove plant that belongs to the Xylocarpus genus i.e. X. moluccensis is also reported for it's antidiarrhoeal activities. The methanol bark extracts of $X$. moluccensis exhibited significant antidiarrhoeal activity in castor oil and magnesium sulphate induced diarrheal mice models at 250 and $500 \mathrm{mg} / \mathrm{kg}$ doses [21,22]. Structures of some important antidiarrhoeal compounds isolated from Xylocarpus plants have been included in (Figure 2).

\section{Possible Mechanism of Action}

Although there are very few reports are available on the on the isolated compounds from the Xylocarpus species, but assumptions can be made about the possible mechanism of action of these mangrove isolates on their antibacterial and antidiarrhoeal activities. The Xylocarpus plants are known for the occurrence of a characteristic compound called limonoids that have a wide spectrum of biological activities, particularly insecticidal action [72]. Some of the other phytochemical compounds such as glycosides, saponins, tannins, flavonoids, terpenoids, and alkaloids are also reported to have antimicrobial activity [63,73]. The phytochemical screening of these Xylocarpus plants have shown the presence of diverse class of compounds like alkaloids, terpenoids, tannins, glycosides, saponins, steroids, coumarins etc. which may be responsible for its antimicrobial activities against a wide range of microbes including Gram positive and Gram negative bacteria, yeast, fungi [60].

Diarrhoea is usually a result of gastrointestinal infection, which can be caused by a variety of bacterial, viral and parasitic organisms. Further, disturbances in the transport of electrolytes and water in the intestines give rise to diarrhoea leading to increased luminal osmolarity, increased electrolyte secretion, decreased electrolyte absorption and deranged intestinal motility causing a decreased transit time [73]. Studies on X. granatum, and X. moluccensis revealed that these plants are rich in potential antidiarrhoeal bioactive compounds like tannins, tannic acid, flavonoids, alkaloids, sesquiterpenes, diterpenes, terpenes and terpenoids [21] that can be utilized in antidiarrhoeal drug development [69]. The complex content of chemicals derived from these plants may have multiple targets of action and might therefore have several potential effects against diarrhoeal disease. The involvement of synergistic effects of astringent and antibacterial effect in combination with decreased intestinal movements might be responsible for their antidiarrhoeal potentials.

\begin{tabular}{|l|l|l|l|}
\hline Plant name & Plant part (s) used & Test method & Compounds identified \\
\hline X. granatum & $\begin{array}{l}\text { Ethanol extract of stem } \\
\text { bark, leaves and fruits }\end{array}$ & - Castor oil induced diarrhoeal model & $\begin{array}{l}\text { Gedunin, Photogedunin, Palmitic acid. } \\
\text { Flavonoids, tannins, saponins, anthraquinone }\end{array}$ \\
\hline X. moluccensis & Methanol extracts of bark & $\begin{array}{l}\text { - Magnesium sulphate-induced diarrhea models. [61], [70] } \\
\text { - Gastrointestinal motility model } \\
\text { - The disc-diffusion method }\end{array}$ & $\begin{array}{l}\text { flavan-3-ols and } \\
\text { procyanidins }\end{array}$ \\
\hline X. mekongensis & NR & NR & NR \\
\hline
\end{tabular}

Table 4: Antidiarrhoeal activities of Xylocarpus species.

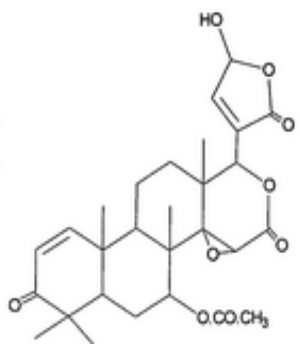

Photogedunin

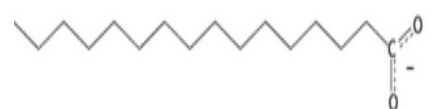

Palmitic acid

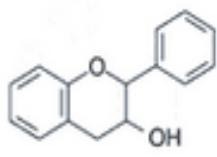

Flavan-3-ols

Figure 2: Structure of some antidiarrhoeal phytoconstituents reported from Xylocarpus sp. 


\section{Future Prospects and Conclusion}

The mangrove plants inhabit a unique ecological habitat exemplified by various stress conditions like high salinity, water logging, low oxygen condition, light stress, low nutrition conditions are reported to be biochemically unique and possess several bioactive compounds. Compounds isolated from the mangrove species have the potential to act as lead compounds for drug discovery. The different mangrove species of Xylocarpus possess significant pharmacological activities which can be pharmaceutically exploited. These plants have shown promising therapeutic applications in treatment of various ailments particularly in microbial infection and diarrhoea as reported by various ethnomedicinal and experimental studies. Even though extracts from mangroves and mangrove-associated species possess therapeutically activity moieties against a number of diseases, the specific metabolites responsible for these bioactivities are remained to be elucidated.

The bioactive compounds isolated from mangrove plants like Xylocarpus have advantages over the conventional medicines as the ethnomedicinal studies suggested that the diversified chemical content from these plants have multiple targets of action and might therefore have several potential therapeutic effects against diarrhoeal diseases. The involvement of synergistic effects of astringent and antibacterial effect of these plant extracts in combination with decreased intestinal movements may play vital role for their antidiarrhoeal potentials. However, safety, adverse effects and toxicity assays of these plant products has to be carried out in order to have a basis of these mangrove plant species to be recommended as phytomedicines useful against diarrhoea. Though many plants have been used in folklore medicine worldwide, recently, extracts from mangroves and their associated species have been proven to possess antimicrobial activities against a number of human, animal and plant pathogens.

The information presented in this review clearly indicates that the different mangrove species of Xylocarpus viz. X. granatum, $X$. moluccensis and $X$. mekogenesis possess pharmacologically active compounds such as alkaloids, flavonoids, limonoids, terpenoids, phenolic glycosides etc. having enormous therapeutic potential in alleviating a number of ailments. However, bioactivity guided isolation of these phytoconstituents is needed to establish the activity-structure relationship that may reveal the bioactive compounds responsible for different pharmacological activities in general and antimicrobial and antidiarrhoeal activities in particular.

\section{References}

1. Simlai A, Roy A (2013) Biological activities and chemical constituents of some mangrove species from Sundarban estuary: An overview. Pharmacogn Rev 7: $170-178$.

2. Kathiresan K and Rajendran N (2005) Mangrove ecosystems of Indian Ocean. Indian J Mar Sci 34: 104-113.

3. Edreva A, Velikova V, Tsonev T, Dagnon S, Gurel A, et al. (2008) Stressprotective role of secondary metabolites: diversity of functions and mechanisms. Gen Appl Plant Physiol 34: 67-78

4. Bandaranayake WM (2002) Bioactivities, bioactive compounds and chemical constituents of mangrove plants. Wetlands Ecol Mangt 10: 421-452.

5. Prabhakaran J, Kavitha D (2012) Ethnomedicinal importance of Mangrove species of Pitchavaram. Int J Res Pharma Biomed Sci 3: 611-614.

6. Rout P, Basak UC (2012) Antioxidant Properties in Leaf and Root Extracts of Some Medicinally Important Mangrove Species of Odisha Coast. Am J PharmTech Res 4: 1-13.

7. Uddin SJ, Nahar L, Shilpi JA, Shoeb M, Borkowski T, et al. (2007) Gedunin, a limonoid from Xylocarpus granatum, inhibits the growth of $\mathrm{CaCo}-2$ colon cancer cell line in vitro. Phytother Res 21: 757-761.
8. Srivastava AK, Tiwari P Srivastava SP, Srivastava R, Mishra A (2014) Antihyperglycaemic and antidyslipidemic activities in ethyl acetate fraction of fruits of marine mangrove Xylocarpus moluccensis. Int J Pharm Pharm Sci 6: 809-826.

9. Singh S, Sharma S, Nath C, Rath SK, Singh RK, et al. (2014) Essentia Safety Pharmacology and safety evaluation of bioactive fraction of Xylocarpus moluccensis: an antidyslipidaemic agent. Int J Med Sci Clin Inven 1: 24-47.

10. Alam MA, Sarder M, Awal MA, Sikder MMH, Daulla KA (2006) Antibacterial activity of the crude ethanolic extract of Xylocarpus granatum stems bark. Bangl J Vet Med 4: 69-72.

11. Rouf R, Uddin SJ, Shilpi JA, Alamgir M (2007) Assessment of antidiarrhoeal activity of the methanol extract of Xylocarpus granatum bark in mice model. $J$ Ethnopharmacol 109: 539-542.

12. Du S, Wang M, Zhu W, Qin Z (2009) A new fungicidal lactone from Xylocarpus granatum (Meliaceae). Nat Prod Res 23: 1316-1321.

13. Lakshmi V, Mishra V, Palit G (2014) A new gastroprotective effect of limonoid compounds xyloccensins $\mathrm{x}$ and $\mathrm{y}$ from xylocarpus molluccensis in rats. Nat Prod Bioprospect 4: 277-283

14. Trilochana $Y$, Sowjanya $P$, Sangeetha GPV, Rajeswara PR, Rajeswara PR (2013) Cardiotonic Activity of Alcoholic Bark Extract of Xylocarpus granatum with Emphasis on Its Mechanism of Action . Iosrphr 3: 4-9.

15. Banerjee LK, Rao TA (1990) Mangroves of orissa coast and their ecology Botanical Survey of India

16. Mulholland DA, Taylor DAH (1992) Limonoids from Australian members of the Meliaceae. Phytochemistry 31: 4163-4166.

17. Wati HN, Taha MR (2010) Taxonomy, distribution and propagation of Xylocarpus species at Carey Island-the heritage island of Malaysia. International Conference on Landscape and Urban Horticulture.

18. Krippner S (2003) Models of Ethnomedicinal Healing. Paper Presented at the Ethnomedicine Conferences, Munich, Germany. April 26-27 and October 1112.

19. Wangensteen $\mathrm{H}$, Alamgir M, Duong GM, Gronhaug TE, Samuelsen AB, et al (2009) Chemical and biological studies of medicinal plants from the Sundarbans mangrove forest. Adv Phytother Res 1: 59-78.

20. Bandaranayake WM (1998) Traditional and medicinal uses of mangroves Mangroves Salt Marshes 2: 133-148.

21. Wangensteen $H$, Klarpas L, Alamgir M, Samuelsen ABC, Malterud K E (2013) Can Scientific Evidence Support Using Bangladeshi Traditional Medicinal Plants in the Treatment of Diarrhoea? A Review on Seven Plants. Nutrients 5: $1757-1800$

22. Uddin SJ, Shilpi JA, Alam SM, Alamgir M, Rahman MT, et al. (2005) Antidiarrhoeal activity of the methanol extract of the barks of Xylocarpus moluccensis in castor oil- and magnesium sulphate-induced diarrhoea models in mice. J Ethnopharmacol 101: 139-143.

23. Uddin SJ, ShilpiJA, RoufR, Ferdous MM, Nahar L, et al. (2006) Antinociceptive activity of some Bangladeshi medicinal plant extracts. Opem 6: 96-101.

24. Ghani A (1998) Medicinal Plants of Bangladesh. (1st edn), Asiatic Society of Bangladesh, Dhaka pp: 592.

25. Jahan IA, Hossain MH, Nimmi I, Islam S, Kawsar MH (2012) Evaluation of anti-inflammatory and antioxidant potential of the kernel root of Xylocarpus mekongensis (Lamk.) M. Roem. Oriental Pharmacy and Experimental Medicine 12: $181-188$

26. Shen LR, Guo D, Yu YM, Yin BW, Zhao L, et al. (2009) Chemical constituents of plants from the genus Xylocarpus. Chem Biodivers 6: 1293-1308.

27. Chou FY, Hostettmann K, Kubo I, Nakanishi K, Taniguchi M (1977). Isolation of an insect antifeedant $\mathrm{N}$ Methylflindersine and several benz (C) Phenanthridine alkaloids from east African plants; a comment on chelerythrine. Heterocycles 7: 969-977.

28. Cheng F, Zhou Y, Zou K, Wu J (2009) Studies on the chemical constituents of the fruit of Xylocarpus granatum. Zhong Yao Cai 32: 1220-1223.

29. Cui J, Ouyang J, Deng Z, Lin W (2008) Structure elucidation of an unprecedented alkaloid and a new limonoid from Xylocarpus granatum. Magn Reson Chem 46 894-897. 
Citation: Das SK, Samantaray D, Thatoi H (2014) Ethnomedicinal, Antimicrobial and Antidiarrhoeal Studies on the Mangrove Plants of the Genus Xylocarpus: A Mini Review. J Bioanal Biomed S12: 004. doi:10.4172/1948-593X.S12-004

30. Zhou ZF, Guo YW (2012) Bioactive natural products from Chinese marine flora and fauna. Acta Pharmacol Sin 33: 1159-1169.

31. Sundarasivarao B, Nazma A, Madhusudhanarao J (1977) Antifungal activity of gedunin. Curr Sci 46: 714-716.

32. Okorie DA, Taylor DAH (1970). Limonoids for Xylocarpus granatum. J Chem Soc 2: $211-13$

33. Wangensteen $H$, Duong GM, Alamgir M, Sarder M, Samuelsen AB, et al. (2006) Biological activities of limonoids, catechins, procyanidins and extracts from Xylocarpus granatum. Nat Prod Commun 1: 985-990.

34. Cui J, Deng Z, Li J, Fu H, Proksch P, et al. (2005) Phragmalin-type limonoids from the mangrove plant Xylocarpus granatum. Phytochemistry 66: 2334-2339.

35. Wu J, Zhang S, Xiao Q, Quingxin L, Xiao L, et al. (2003) Xyloccensin M and N two new B, D-seco limonoids from Xylocarpus granatum. Z Naturforsch 58b: 1216-1219.

36. Wu J, Zhang S, Xiao Q, Quingxin L, Xiao L, et al. (2004b) Xyloccensin L, a novel limonoid from Xylocarpus granatum. Tetrahedron Lett 45: 591-593.

37. Wu J, Zhang S, Xiao Q, Quingxin L, Xiao L, et al. (2005a) Xyloccensins Q-V six new 8,9,30-phragmalin ortho ester antifeedants from the Chinese mangrove Xylocarpus granatum. Tetrahedron 61: 8382-8389.

38. Yin S, Fan CQ, Wang XN, Lin LP, Ding J, et al. (2006) Xylogranatins A-D: novel tetranortriterpenoids with an unusual 9,10 -seco scaffold from marine mangrove Xylocarpus granatum, State Key Laboratory of Drug Research, Institute of Materia Medica, Shanghai Institutes for Biological Sciences. Chin Acad Sci 12: 4935-4938.

39. Pan JY, Chen SL, Li MY, Li J, Yang MH, et al. (2010) Limonoids from the Seeds of a Hainan Mangrove, Xylocarpus granatum. J Nat Prod 73: 1672-1679.

40. Lakshmi V, Gupta P (2008) An overview of the genus Xylocarpus. Nat Prod Res 22: 1197-1224.

41. Hu WM, Wu J (2010) Protoxylogranatin B, a Key Biosynthetic Intermediate from Xylocarpus granatum: Suggesting an Oxidative Cleavage Biogenetic Pathway to Limonoid. Open Nat Prod J 3: 1-5.

42. Wangensteen $H$, Alamgir M, Duong GM, Gronhaug TE, Samuelsen $A B$, et al (2010) Chemical and Biological Studies of Medicinal Plants from the Sundarbans Mangrove Forest In mohamed eddouks. Advances in Phytotherapy Research. Research Signpost pp. 59-78.

43. Okorie DA, Taylor DAH (1977) Limonoids from Xylocarpus granatum Koenig J Chem Soc 46: 211-213.

44. Vadlapudi V, Naidu KC (2009) Evaluation of antioxidant potential of selected mangrove plants. J Pharma Res 2: 1742-1745.

45. Srivastava AK, Srivastava S, Srivastava SP, Raina D, Ahmad R, et al. (2011) Antihyperglycemic and antidyslipidemic activity in ethanolic extract of a marine mangrove Xylocarpus granatum. J Pharm Biomed Sci 9: 22.

46. Bickii J, Njifutie N, Foyere JA, Basco LK, Ringwald $P(2000)$ In vitro antimalarial activity of limonoids from Khaya grandifoliola C.D.C. (Meliaceae). J Ethnopharmacol 69: 27-33.

47. Okeke MI, Iroegbu CU, Eze EN, Okoli AS, Esimone CO (2001) Evaluation of extracts of the root of Landolphia owerrience for antibacterial activity. J Ethnopharmacol 78: 119-127.

48. Shahid-Ud-Daula AFM, Basher MA (2009) Phytochemical screening, plant growth inhibition, and antimicrobial activity studies of Xylocarpus granatum. Malays J Pharm Sci 7: 9-21.

49. Khairina ASN, Fuad AFA, Muhammad TST, Ahmad A, Faridah M (2011) In vitro cytotoxicity screening of Xylocarpus sp. crude extracts against human hepatocellular carcinoma cell line (HepG2). Empowering Science Technology and Innovation towards a Better Tomorrow, UMTAS 704-706.

50. Chacha M (2010) Flavanol derivatives with antioxidant activity from the stem bark of Xylocarpus granatum. Int J Biol Chem Sci 4: 371-376.

51. Kokpol U, Chavasiri W, Tip-pyang S, Veerachato G, Zhao F, Jim S, et al. (1996) A limonoid from Xylocarpus granatum. Phytochemistry 41: 903-905.

This article was originally published in a special issue, Development of Phyłochemicals as Drugs handled by Editor. Dr. Erik de Leeuw, University of Maryland, USA
52. Alvi KA, Crews $P$, Aalbersberg B, Prasad R (1991) Limonoids from the fijian medicinal plant dabi (Xylocarpus). Tetrahedron 4: 8943-8948.

53. Babu BH, Lakshmi MS, Kumar AS (2010) A review on traditional system of medicine for treats epilepsy. Int J Biol Pharma Res 1: 1-6.

54. Prihanto AA (2007) Cytotoxic, antioxidant and antibacterial activity of methano extract of Xylocarpus moluccensis fruit husk. Proceeding of The International Conference on Basic Science held at Malang, Indonesia: Galaxy Science publisher pp 2-5.

55. Haque ME, Islam MN, Rahman MH, Mohamad AU (2007) Antimicrobial and cytotoxic activities of the crude extracts and isolated compounds of Xylocarpus mollucensis. DUJPS 6: 109-112.

56. Ahmed A, Labu Z, Dey SK, Hira A, Howlader MSI, et al. (2013) Phytochemical Screening, Antibacterial and Cytotoxic Activity of Different Fractions of Xylocarpus mekongensis Bark. Ibnosina J Med BS 5: 206-213.

57. Hoque MM, Sabrin F, Alam SMN, Khatun MA, Billah MM (2012) Cytotoxic activity of chloroformic extracts of Xylocarpus mekongenesis (Lamk.) M. Roem. and Cerbera manghas. J Innov Dev Strategy 6: 29-34.

58. Uddin SJ, Grice ID, Tiralongo E (2011) Cytotoxic effects of bangladesh medicinal plant extracts. Evid Based Complement Alternat Med 2011: 578092

59. Cowan MM (1999) Plant products as antimicrobial agents. Clin Microbiol Rev 12: $564-582$

60. Patra JK, Mohanta YK (2014) Antimicrobial compounds from mangrove plants A pharmaceutical prospective. Chin J Integr Med

61. Choudhury S, Sree A, Mukherjee SC, Pattnaik P, Bapuji M (2005) In vitro activity of extracts of selected marine algae and mangrove against fish pathogens. Asian Fish Sci 18: 285-294.

62. Rao PR, Trilochana Y, Chaitanya KK (2003) Anti-diarrhoeal and antimicrobial activities of bark and leaf extracts of Xylocarpus granatum Koenig. J Nat Rem 3: $155-160$.

63. Mondal S, Paul SK, Uddin SJ, Nahar L, Auzi AA, et al. (2008) A comparative study on the in vitro antibacterial activity of the pneumatophores of Heritiera fomes and Xylocarpus moluccensis. Ars Pharm 49: 51-56.

64. Veni PS, Sunita S, Srinivasulu A (2014) Antibacterial and phytochemica screening of Xylocarpus moluccensis leaf and stem on selected drug resistant and sensitive bacteria. Int J Microbiol Res 5: 30-34.

65. Bamroongrugsa N (2008) Bioactive substances from mangrove resources Songklanakarin J Sci Technol 21: 377-386.

66. Shinoda Y, Ogisu M, Iwata S, Tajima T (1985) The chemical composition of mangroves II. Gifu Daigaku Nogakubu Kenkyu Hokoku 50: 155-165.

67. Shoba FG, Thomas M (2001) Study of antidiarrhoeal activity of four medicinal plants in castor-oil induced diarrhoea. J Ethnopharmacol 76: 73-76.

68. Sarin RV, Bafna PA (2012) Herbal Antidiarrhoeals: A Review. Int J Pharm Biomed Res 3: 637-649.

69. Lakhsmi V, Saxena A, Singh S, Pal R, Srivastava S, et al. (2006) A process for the isolation of standardized antidiarrhoeal fraction and its active compounds from the fruit seed coat of Xylocarpus granatum Koen and its use.

70. Lakshmi V, Srivastava MN Raghubir R (2011) Antidiarrhoeal activity in fruits of Xylocarpus granatum. Asian J Phar Biol Res 2011: 62-66.

71. Ambrozin ARP, Leite AC, Bueno FC, Vleira P C, Fernandes JB, et al. (2006) Limonoids from Andiroba Oil and Cedrela fissilis and their insecticidal activity. J Brazilian Chem Soc 17: 542-547.

72. Ebi GC, Ofoefule SI (1997) Investigating into folkloric antimicrobial activities of Landolphia owerrience. Phytother Res 11: 149-151.

73. Lutterodt GD (1992) Inhibition of Microlax-induced experimental diarrhoea with narcotic-like extracts of Psidium guajava leaf in rats. J Ethnopharmacol 37 151-157. 